\title{
Revised stratigraphy of the Cookson Group of southwestern New Brunswick and adjacent Maine
}

\author{
L.R. Fyffe \\ Mineral Resources, Department of Natural Resources and Energy, P.O. Box 6000, \\ Frederirton, New Brunswick E3B 5H1, Canada
}

and

\author{
J. Riva
}

Department of Geology, Université Laval, Ste-Foy, Québec G1K 7P4, Canada

Date Received July 31, 1990

Date Accepted October 12, 1990

\begin{abstract}
The Ordovician Cookson Group in southwestern New Brunswick is divided into formations previously recognized in the adjacent area of Maine. However, the stratigraphic order of these formations is revised based on new fossil evidence. From the base upward, the revised Cookson Group comprises the Calais, Woodland, Pocomoonshine Lake, and Kendall Mountain formations; the latter formation contains newly discovered Caradocian graptolites.

The Digdeguash Formation, previously assigned to the Silurian, is now included in the Cookson Group, and is considered to be equivalent to the Woodland and Pocomoonshine Lake formations on the basis of lithological similarities. The contact between the Digdeguash Formation and the Silurian Flume Ridge Formation, previously interpreted to be gradational, is a major fault.
\end{abstract}

Le Groupe de Cookson du sud-ouest du Nouveau-Brunswick est divisé en formations a déjà que l'on identifiées dans la région adjacente du Maine. Cependant l'ordre stratigraphique de ces formations a été révisé suite à la découverte d'un nouveau site fossilifere. A partir du bas, le Groupe de Cookson révisé comprend les formations de Calais, Woodland, Pocomoonshine Lake et de Kendall Mountain; cette demière contient des graptolites nouvellement découverts appartenant à l'Ordovicien moyen (Caradocien).

La Formation de Digdeguash, antérieurement considérée comme faisant partie du Silurien, est maintenant intégrée au Groupe de Cookson. La Formation de Digdeguash représente un faciès similaire à celui des formations Woodland et Pocomoonshine Lake. La zone de contact entre la Formation de Digdeguash et la Formation de Flume Ridge, d'âge silurien, antérieurement considérée comme graduelle est, en effet, une fait importante.

\section{INTRODUCTION}

The Cookson Group of southwestern New Brunswick and Maine represents a distinctive Ordovician stratigraphic package that has been referred to as the St. Croix Terrane (Fig. 1) by Fyffe and Fricker (1987). Establishing a reliable internal stratigraphy for the Cookson Group is vital to the reconstruction of the paleogeographic relationship between the North American craton and the Precambrian Avalonian Terrane, presently situated southeast of the St. Croix Terrane (Fig. 1).

Interpretation of the early Paleozoic stratigraphy in the region has proven to be difficult because of complex deformation, poor exposure, and lack of fossils; and controversy exists as to the nature of the contacts between Ordovician rocks of the St. Croix Terrane and adjoining Silurian rocks. A long standing problem has been to reconcile the apparent unconformable relationship between fossiliferous Lower Ordovician (St. Croix Terrane) and Upper Silurian rocks (Mascarene Cover Sequence) on Cookson Island in Passamaquoddy Bay with the apparently conformable relationship between unfossiliferous rocks assigned to the Ordovician and Silurian farther inland.

Ruitenberg (1967) proposed a formal stratigraphic nomenclature for the area, placing the Ordovician rocks in the Cookson Formation; supposed Silurian rocks, exposed inland to the northwest, were placed in the Digdeguash Formation and the gradationally overlying Flume Ridge Formation (Fredericton Cover Sequence, Fig. 1). The contact between the Cookson and Digdeguash formations was interpreted by Ruitenberg (1967) to be a thrust fault, which he named the Honeydale Fault.

Ludman (1987) recently divided the Cookson Group into four formations in Maine. He proposed the following stratigraphic order for the newly established units from the base upward: 


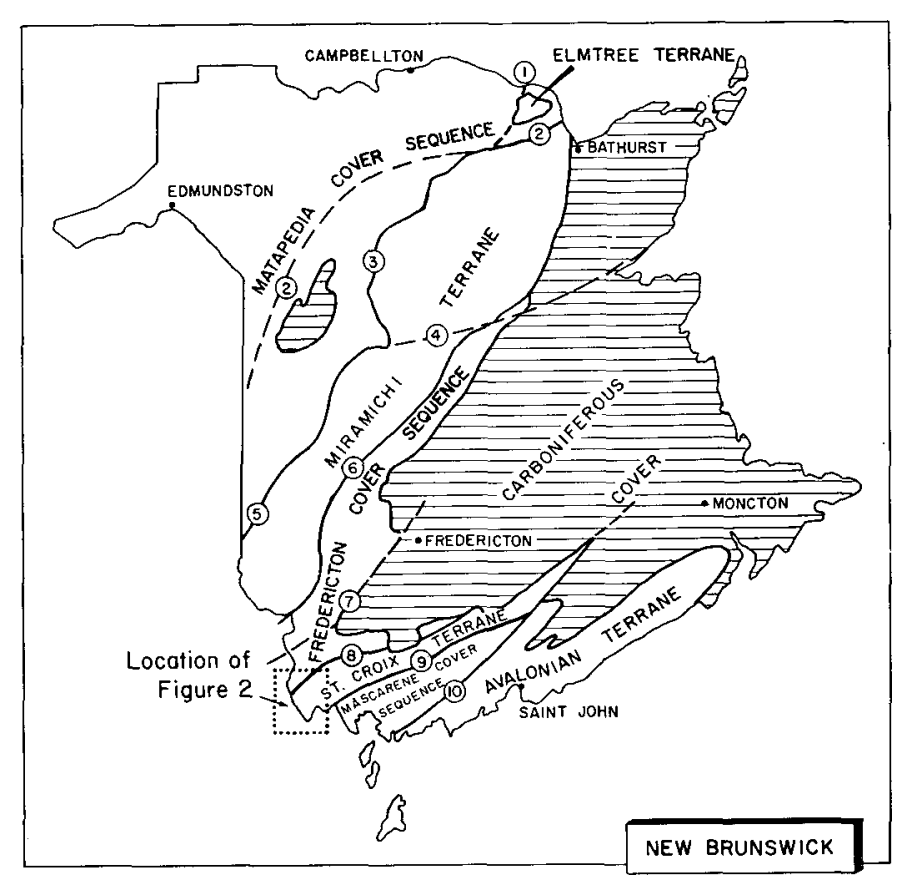

Fig 1. Tectonostratigraphic terranes and cover sequences of New Brunswick after Fyffe and Fricker (1987). Location of Figure 2 is shown. The Elmtree and Miramichi terranes are, respectively, early Ordovician oceanic crust and ensialic volcanic rocks generated in a back-arc setting. The St. Croix Terrane is an Ordovician sedimentary clastic wedge presumably deposited off the margin of the Avalonian Terrane. The Avalonian Terrane comprises mainly Precambrian volcanic and sedimentary rocks. The Matapédia, Fredericton, and Mascarene cover sequences are sedimentary and volcanic rocks that were deposited between the Late Ordovician and Early Devonian (after Fyffe and Fricker 1987). Faults: 1 - Jacquet River, 2 - Rocky Brook-Millstream, 3 - Portage Lakes-Serpentine River, 4 - Catamaran, 5 - Woodstock, 6 Bamford Brook, 7 - Fredericton, 8 - Basswood Ridge-Pendar Brook, 9 - Falls Brook-Taylor Brook, and 10 - Belleisle-Wheaton Brook.

Pocomoonshine Lake Formation, Kendall Mountain Formation, Woodland Formation, and Calais Formation. The Calais Formation was known to be Early Ordovician from palaeontological evidence, so the supposedly underlying formations were assigned to the Late Cambrian.

A largely unmapped portion of the St. Croix Terrane, lying between the Maine-New Brunswick border and Moores Mills Lake to the north of St. Stephen (Fig. 2), was surveyed in the summer of 1989 (Fyffe, 1990). Formation divisions established in Maine were successfully extended into New Brunswick but the discovery of fossils in the Kendall Mountain Formation indicates that the stratigraphic sequence is generally the reverse of that suggested by Ludman (1987). The stratigraphic position of the Pocomoonshine Lake Formation, which does not extend into New Brunswick, remains unchanged (Fig. 3). The current investigation has also revealed the presence of a fault between the Digdeguash and Flume Ridge formations, requiring the reevaluation of the St. Croix Terrane/Fredericton Cover Sequence boundary and the relationship of the Fredericton to the Mascarene Cover Sequence (Fig. 1).

\section{STRATIGRAPHY}

The Calais Formation can be traced from its type locality on the St. Croix River at the border towns of Calais and St. Stephen as far eastward as Oak Bay (Fig. 2). The formation comprises black carbonaceous shale interstratified with minor thin-bedded siltstone. A pillowed basalt member, about $100 \mathrm{~m}$ thick, occurs near the top of the formation. The flows have been thermally metamorphosed to a plagioclase-actinolite-biotite-sphene-iron oxide assemblage during emplacement of nearby Devonian gabbroic plutons. The basalt is moderately evolved with traceelement abundances similar to some passive continental margin tholeiites (Fyffe et al., 1988). Black shales in the contact aureoles contain abundant cordierite and andalusite porphyroblasts.

A thick sandstone-rich sequence, to the northwest of St. Stephen, apparently conformable with the Calais Formation, has been divided into two formations, i.e., Woodland and Kendall Mountain formations (Fig. 2). The Woodland Formation contains rhythmically interstratified, thin- to medium-bedded (2-20 $\mathrm{cm}$ ), well-graded, quartzofeldspathic wacke (locally containing calcareous nodules) and lesser interlaminated siltstone and shale. The Kendall Mountain Formation is characterized by medium - to thick-bedded $(10 \mathrm{~cm}-2 \mathrm{~m})$ quartz arenite with thin interbeds of black shale. The contact with the Woodland Formation is gradational and placed where quartz arenite exceeds wacke in abundance. A 1 m-thick light green tuff bed, exposed on Mohannes Stream, presumably correlates with volanic rocks mapped by Ludman (1987) in the Kendall Mountain Formation near its contact with the Woodland Formation. The Kendall Mountain Formation is estimated to be between 500 to $700 \mathrm{~m}$ thick and the Woodland, about $800 \mathrm{~m}$ thick (Ludman, 1987). Metamorphism in the two formations varies from cordierite- to sillimanite-grade (Fig. 2).

Interlaminated light grey siltstone and dark grey shale interstratified with lesser thin- to medium-bedded quartzo-feldspathic wacke, exposed to the northwest of the Kendall Mountain Formation, were included in the Digdeguash Formation by Ruitenberg (1967). Although unfossiliferous, these biotite-grade rocks were considered to be Silurian in age and to be separated from the Kendall Mountain Formation (then part of the undivided Cookson Formation of Ruitenberg, 1967) by the Honeydale Fault. However, according to the recent mapping, the section between the Digdeguash and Kendall Mountain formations appears to be at least locally continuous near Moores Mills Lake, where the similarity of the laminated siltstone and shale beds in the two sequences suggests that both belong to the Ordovician Cookson Group. Moreover, newly exposed calc-silicate beds in the Digdeguash Formation along the highway northwest of Moores Mills Lake are similar to those in the Woodland Formation. The contact between the Digdeguash Formation and the Kendall Mountain Formation in Maine is defined by the Crawford Fault (Ludman, 1987), which presumably is continuous with the Honeydale Fault of New Brunswick.

The Flume Ridge Formation is an interbedded sequence of micaceous calcareous wacke, siltstone, and shale, which lies below biotite grade in New Brunswick. Although the contact 


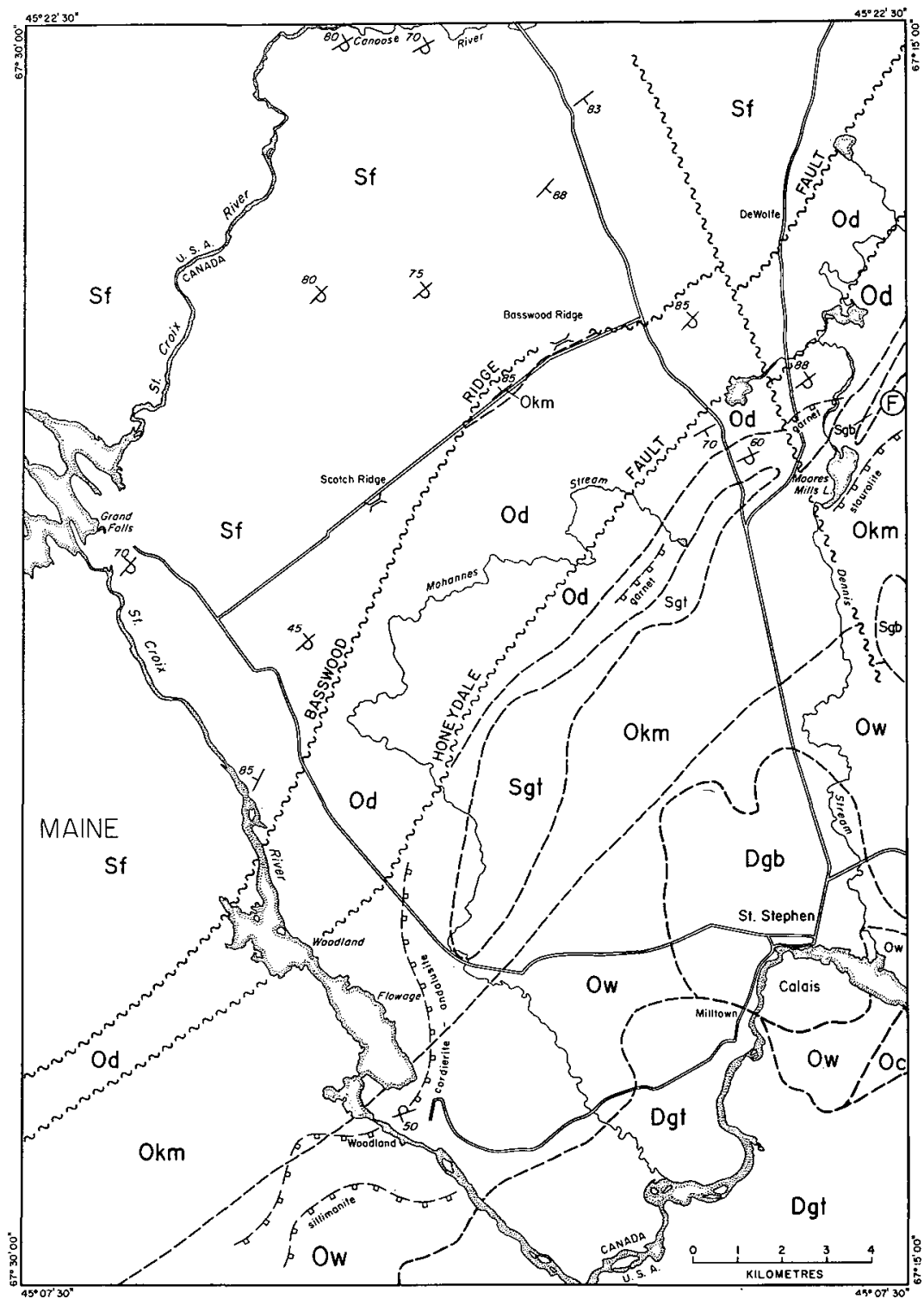

LEGEND

\section{DEVONIAN}

Baring Pluton (Dgt): Pink biotite granite; grey biotite-homblende diorite

St. Stephen Pluton (Dgb): Peridotite, anorthosite, layered troctolite, norite, and gabbro

\section{SILURIAN}

Mohannas Pluton (Sgt): Light grey, cataclastic biotite granodiorite containing augen of plagioclase; minor gabbro

Allen Brook Pluton (Sgb): Dark green, foliated gabbro

Flume Ridge Formation (Sn): Light grey, thin- to medium-bedded micaceous, calcareous wacke and siltstone interstratified with light green to medium grey slate

\section{ORDOVICIAN}

\section{COOKSON GROUP}

Kendall Mountain Formation (Okm): Light grey, medium- to thick-bedded quartz arenite interstratified with black carbonaceous slate; minor pebble conglomerate and tuff

Digdeguash Formation (Od) and Woodland Formation (Ow): Dark and light grey laminated siltstone and shale interstratified with thin- to medium-bedded, grey quartzofeldspathic wacke (locally containing calcareous beds); wacke dominates the Woodland Formation, whereas siltstone and shale dominate the Digdeguash Formation

Calais Formation (Oc): Black carbonaceous slate, minor siltstone and pillow basalt

Fig. 2. Geologic map of the western portion of the St. Croix Terrane. Location of new fossil discovery is shown by circled "F". 


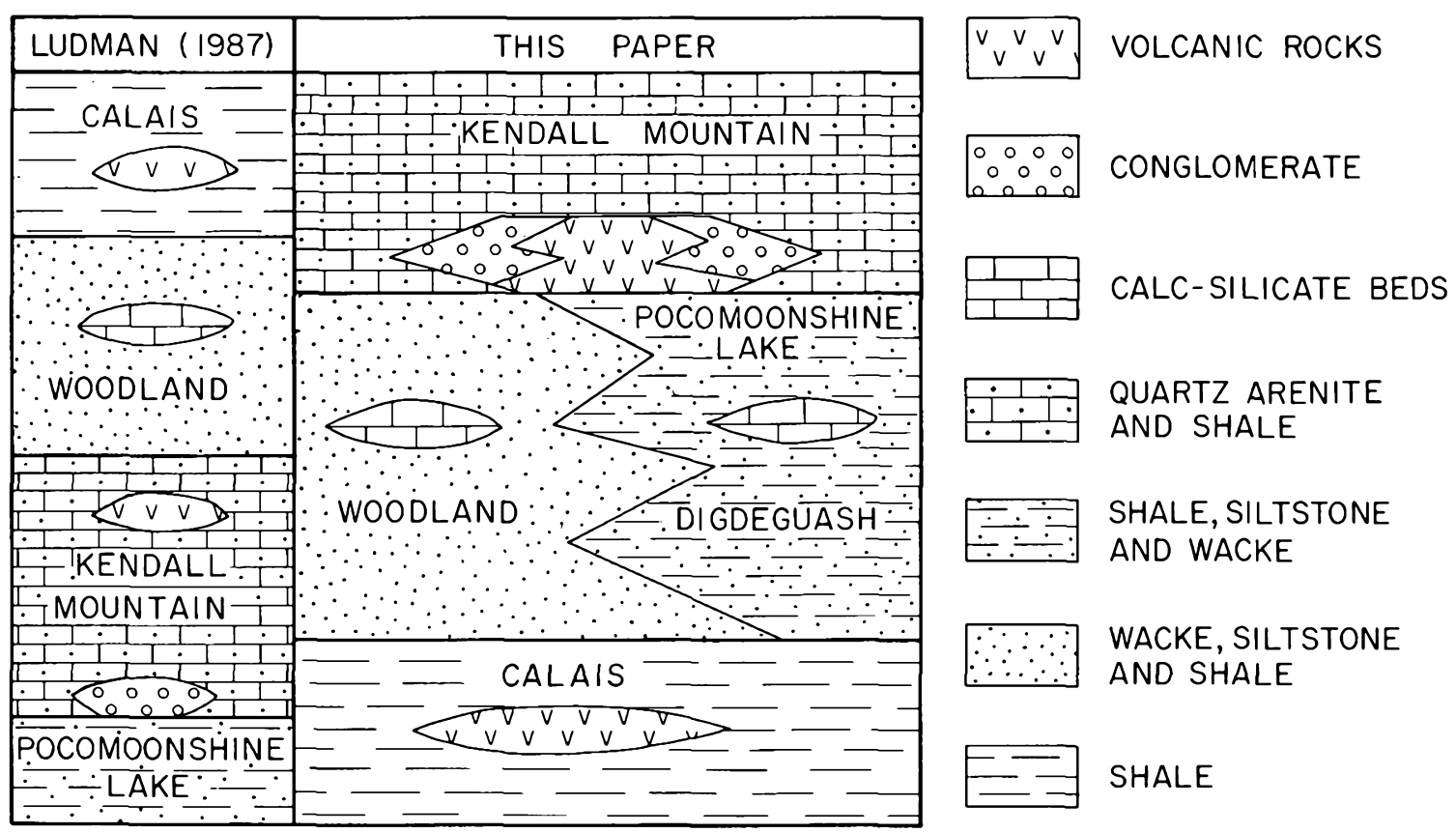

Fig. 3. Schematic illustration of stratigraphic relationships proposed for the Cookson Groupcompared to previous interpretation from Ludman (1987).

between the Flume Ridge and Digdeguash formations has been regarded as gradational, recent mapping proves it to be tectonic (Fig. 2). The fault zone is prominantly exposed on Basswood Ridge, where it is injected by $2 \mathrm{~m}$-thick quartz veins, and on Cox Brook (to the east of the Moores Mills Lake area), where it is intruded by granite porphyry dykes (Fyffe, 1990).

\section{PALEONTOLOGICAL IMPLICATIONS}

The Early Ordovician (Arenigian) graptolite Clonograptus herrmanni Manson has previously been reported from the Calais Formation (Cumming, 1967). However, re-examination of the Cookson Island specimens indicate that they could well belong to the newly-redefined and expanded Adelograptus tenellus (Linnarsson), although deformation does not allow for the recognition of bithecae. The specimens show the same degree of deformation as the neotype of the species and the other type material figured by Maletz and Erdtmann (1987), which also show no traces of bithecae. This species, according to Maletz and Erdtmann (1987), has hitherto only been positively identified in Scandinavia, the Baltic area, Great Britain and possibly North Africa where it occurs just above the Rhabdinopora (= Dictyonema) flabelliformis Zone of the lower Tremadoc.

Because the Woodland and Kendall Mountain formations were interpreted on the basis of rare primary sedimentary structures to be stratigraphically below the Early Ordovician Calais Formation, they were assigned a Late Cambrian age (Ludman, 1987). However, graptolites recently recovered from black shales of the Kendall Mountain Formation northeast of Moores Mills Lake (Fig. 2) have been identified as "Diplograptus" foliaceous (Murchison), Corynoidessp., Climacograptus sp.,Dicranograptus sp., and glyptograptids, an assemblage suggestive of the Climacograptus wilsoni Zone of the Caradocian (mid-Ordovi- cian). This new paleontological evidence effectively reverses the stratigraphic order proposed by Ludman (1987) so that the intervening Woodland Formation must lie stratigraphically above the Calais Formation and beneath the Kendall Mountain Formation (Fig. 3). Furthermore, a re-evaluation of the stratigraphic relationships of other formations included in the Cookson Group is required.

The only rocks previously mapped as being stratigraphically below the Kendall Mountain Formation are grey to black shales, siltstones, and fine-grained, graded sandstones of the Pocomoonshine Lake Formation (Ludman, 1987). These rocks are exposed in Maine along the northwestern boundary of the Kendall Mountain Formation, immediately west of the area shown in Figure 2. There, thick beds of pebble conglomerate, containing abundant volcanic detritus, occur locally in the Kendall Mountain Formation near its conformable contact with the underlying Pocomoonshine Lake Formation. This conglomerate must occupy approximately the same stratigraphic position as the volcanic rocks interbedded with the Kendall Mountain Formation along its contact with the underlying Woodland Formation to the southeast (noted above). The conglomerate, therefore, may have been derived by contemporaneous erosion of the volcanic rocks. Together the volcanic rocks and conglomerate serve to characterize the lower part of the Kendall Mountain Formation (Fig. 3).

A bed of similar conglomerate also occurs along the contact between siltstone and shale of the Digdeguash Formation and quartz arenites of the Kendall Mountain Formation just north of Moores Mills Lake in New Brunswick (Fig. 2). Thus, a correlation can be made between the Pocomoonshine Lake Formation and upper part of the Digdeguash Formation (Fig. 3), an interpretation supported by the southeast-facing of graded calc-silicate beds in the Digdeguash Formation, exposed on the highway south from DeWolfe (Fig. 2). 


\section{CONCLUSIONS}

The Digdeguash Formation to the northwest of Moores Mills Lake is a southeast-younging sequence containing laminated siltstone and shale beds that can be correlated with the Pocomoonshine Lake Formation, and calc-silicate wacke beds that suggest a correlation with high-grade metamorphic rocks of the Woodland Formation. The overlying K.endall Mountain Formation, previously considered to be Cambrian, contains Caradocian graptolites and represents the youngest preserved part of the Cookson Group. Therefore, the Kendall Mountain Formation in New Brunswick can be interpreted to occupy the core of a regional synclinal structure. The distribution of the Kendall Mountain Formation in Maine indicates that this syncline closes to the southwest (see fig. 4 of Ludman, 1987), consistent with the generally shallow, northeast-plunge of minor folds in the region. The upper volcanic-bearing, and lower conglomerate-bearing members of the Kendall Mountain Formation defined by Ludman (1987) may, thus, actually be a repetition of the same stratigraphic horizon. The northwestern limb of the syncline is partially faulted out by the Crawford Fault, which could account for the absence of calc-silicate beds in the Digdeguash Formation of Maine.

Previous correlations of the Cookson Group with the Cambrian part of the Saint John Group of the Avalonian Terrane (Ludman, 1987) and lower part of the Tetagouche Group of the Miramichi Terrane (Rast and Stringer, 1974; Fyffe et al., 1983) are obviously invalidated. Only Tremadocian black shale is common to the Avalonian, Miramichi, and St. Croix terranes (Fyffe et al., 1983; Fyffe et al., 1988; Fig. 1). This black shale could conceivably represent a starved continental-margin facies blanketing the mature southeastern flank of the Early Paleozoic Iapetus Ocean. The later development of volcanism to different degrees in the St. Croix and Miramichi terranes may be related to a mid-Ordovician episode of back-arc spreading (Fyffe $e t$ al., 1990).

Recognition of the Basswood Ridge Fault has important implications for regional tectonic synthesis. Silurian rocks of the Fredericton Cover Sequence (Flume Ridge Formation), located to the northwest of the St. Croix Terrane, can no longer be considered to be laterally or vertically continuous with Silurian strata of the Mascarene Cover Sequence (Oak Bay and Waweig formations), which were deposited along the southeastern boundary of the St. Croix Terrane. The Mascarene Cover Sequence provides an Upper Silurian linkage between the Avalonian and St. Croix terranes as it contains detritus derived locally from the Cookson Group and an Acado-Baltic fauna in common with Silurian rocks of the Avalonian Terrane (Fyffe and Fricker, 1987). Although the Fredericton Cover Sequence contains detritus eroded from Ordovician rocks of the Miramichi Terrane in the northwest, no equivalent connection has yet been demonstrated to the St. Croix Terrane. Therefore, juxtaposition of the Miramichi and St. Croix terranes need not have occurred until later in the Paleozoic history of the Appalachian Orogen.

\section{ACKNOWLEDGEMENTS}

The authors wish to acknowledge Art Ruitenberg and Allan Ludman for their contributions toward the understanding of the geological history of the St. Croix belt, although they do not necessarily agree with our interpretations. Gerry Johnson and Terry Leonard drafted the figures and Kim O'Donnell and Diane Blair typed various versions of the manuscript.

CUMMING, L.M. 1967. Geology of the Passamaquoddy Bay region, Charlotte County, New Brunswick. Geological Survey of Canada, Paper 65-29, $36 \mathrm{p}$.

FYFFE, L.R. 1990. Bedrock geology of the Moores Mills area, Charlotte County, New Brunswick. In Project summaries for 1989, Fourteenth Annual Review of Activities. Edited by S.A. Abbott. New Brunswick Department of Natural Resources and Energy, Minerals and Energy Division, Information Circular 89-2 (second edition), pp. 40-51.

FYFFE, L.R. and FRICKER, A. 1987. Tectonostratigraphic terrane analysis of New Brunswick. Maritime Sediments and Atlantic Geology, 23, pp. 113-123.

FYFFE, L.R., FORBES, W.H., and RIVA, J. 1983. Graptolites from the Benton area of west-central New Brunswick and their regional significance. Maritime Sediments and Atlantic Geology, 19, pp. 117-125.

FYFFE, L.R., STEWART, D.B., and LUDMAN, A. 1988. Tectonic significance of black pelites and basalts in the St. Croix Terrane, coastal Maine and New Brunswick. Maritime Sediments and Atlantic Geology, 24, pp. 281-288.

FYFFE, L.R., VAN STAAL, C.R., and WINCHESTER, J.A. 1990. Late Precambrian-Early Paleozoic volcanic regimes and associated massive sulphide deposits in the nor theastern mainland Appalachians. Canadian Institute of Mining and Metallurgy, Bulletin 83, No. 938, pp. 70-78.

LUDMAN, A. 1987. Pre-Silurian stratigraphy and tectonic significance of the St. Croix Belt, southeastern Maine. Canadian Journal of Earth Sciences, 24, pp. 2459-2469.

MALETZ, J. and ERDTMANN, B.D. 1987. Adelograptus tenellus (Linnarsson 1871): its astogenetic development and its stratigraphic and palaeogeographical distribution. Bulletin of the Geological Society of Denmark, 35, pp. 175-190.

RAST, N. and STRINGER, P. 1974. Recent advances and the interpretation of geological structure of New Brunswick. Geoscience Canada, 1, pp. 15-25.

RUITENBERG, A.A. 1967. Stratigraphy, structure and metallization Piskahegan-Rolling Dam area, northern Appalachians, New Brunswick, Canada. Leidse Geologische Mededelingen, 40, pp. 79-120. 